\title{
The terminal contour of Italian semi-spontaneous instructions
}

Domenico Di Russo

Università di Roma La Sapienza, Italy

https://doi.org/10.36505/ExLing-2011/04/0015/000184

\begin{abstract}
This article aims to analyze the intonative features of instructions in semispontaneous Italian, with particular regard to their terminal contour, in order to understand which is its semantic importance and, from this point of view, what is the nature of relation between intonation and modality.
\end{abstract}

Key words: instruction, intonation, modality, semantics, terminal contour

\section{Introduction}

It is well known that the notion of terminal contour, i.e. the part of the intonative profile that goes from the last tonic syllable to the end of utterance, is the touchstone of studies about relations between intonation and modality, so that the distinctive and intuitively normative character of one-to-one correspondence, or rather coalescence, between few basic terminal contour prototypes and few basic sentence modalities is now generally accepted, even by the most important Italian studies on intonation (Chapallaz 1964; Lepschy 1978; Canepari 1985; De Dominicis 1992; Bertinetto \& Magno Caldognetto 1993; Sorianello 2006).

\section{The case of instructions}

In accordance both with the notion of utterance as a sense unit (Benveniste 1964: 122) that, traced in relation to an enonciative coordinates system (Culioli 1978: 129), displays all cooperating elements which play together to the construction of its signification in continuous, unitary and undivisible unicum of its intonative profile, and with the notion of modality as an active operation of the speaker's rational activity (Bally 1932), in the light of the formal semantics studies tradition inspired by the equally important logic tradition (Lyons 1977, Palmer 1986, Grice 1990), we consider here a particular modality which belongs to one of the five modal classes that we may recognize in spoken language through a tridimensional representative system with an objective (alethic modalities), a subjective (epistemic, appreciative and volitive modalities) and an inter-subjective axis (deontic modalities) (Le Querler 1996: 63-67), i.e. the case of 528 instructions taken from a sample of 15 semi-spontaneous Italian Map Task dialogues recorded in 15 representative Italian cities and selected from the dialogical section of CLIPS corpus (http://www.clips.unina.it). The instructions status consists in giving directions to co-speaker concerning an object, an event or a situation, they

ExLing 2011: Proceedings of 4th Tutorial and Research Workshop on Experimental Linguistics, 25-27 May, Paris, France 
correspond to $81 \%$ of all 652 deontic modalities and $13,5 \%$ of all 3898 modal utterances and are shared out as follows: 57 in the dialogue of Bari (Ba), 37 in that one of Bergamo (Bg), 38 in Cagliari (Ca), 43 in Catanzaro $(\mathrm{Cz}), 45$ in Florence (Fi), 48 in Genoa $(\mathrm{Ge}), 28$ in Lecce (Le), 26 in Milan (Mi), 11 in Naples (Na), 24 in Palermo (Pa), 29 in Parma (Pr), 31 in Perugia $(\mathrm{Pg}), 17$ in Rome (Rm), 53 in Turin (To), 41 in Venice (Ve) (Di Russo 2011).

As we can note considering, for example, the most simple terminal contour profiles and the ones made up by the mix of these simples tunes, terminal contours configuration shows a very great variety (Table 1 ).

Table 1. The terminal contour of instructions

\begin{tabular}{|l|l|l|}
\hline \hline Terminal contour types & Instructions number & Percentage (\%) \\
\hline fall & 42 & 8,0 \\
\hline mid-level & 3 & 0,6 \\
\hline rise & 23 & 4,4 \\
\hline fall-low mid level & 13 & 2,5 \\
\hline fall-rise & 145 & 27,5 \\
\hline mid level-fall & 5 & 0,9 \\
\hline mid level-rise & 14 & 2,7 \\
\hline rise-fall & 13 & 2,5 \\
\hline rise-high mid level & 1 & 0,2 \\
\hline fall-low mid level-fall & 1 & 0,2 \\
\hline fall-low mid level-rise & 3 & 0,6 \\
\hline fall-rise-fall & 26 & 4,9 \\
\hline fall-rise-high mid level & 12 & 2,3 \\
\hline mid-level-fall-low mid level & 1 & 0,2 \\
\hline mid-level-fall-rise & 4 & 0,8 \\
\hline mid-level-rise-fall & 1 & 0,2 \\
\hline rise-fall-low mid level & 1 & 0,2 \\
\hline rise-fall-rise & 17 & 3,2 \\
\hline rise-high mid level-fall & 1 & 0,2 \\
\hline rise-high mid level-rise & 2 & 0,3 \\
\hline others & 200 & 37,9 \\
\hline Total & 528 & 100 \\
\hline \hline
\end{tabular}

If we look at terminal contour types distribution from a diatopical point of view, dwelling above all on the most large ones, we may see that their wide diversity is equally shared by all different dialogues instructions. In descending order, in fact, we can note that the 145 fall-rising types are so distributed: 6 in $\mathrm{Ba}, 11$ in $\mathrm{Bg}, 9$ in $\mathrm{Ca}, 4$ in $\mathrm{Cz}, 14$ in Fi, 19 in Ge, 7 in Le, 4 
in Mi, 4 in Na, 9 in Pa, 15 in Pr, 9 in Pg, 6 in Rm, 23 in To, 5 in Ve. Among the 42 falling types of terminal contour, we can find out: 7 in $\mathrm{Ba}, 4$ in $\mathrm{Bg}, 4$ in $\mathrm{Cz}, 1$ in Ge, 6 in Le, 5 in $\mathrm{Mi}, 1$ in $\mathrm{Pa}, 3$ in $\mathrm{Pr}, 3$ in $\mathrm{Pg}, 1$ in $\mathrm{Rm}, 8$ in $\mathrm{Ve}$. The 26 fall-rise-falling types are so shared out: 8 in Ba, 6 in $\mathrm{Cz}, 1$ in $\mathrm{Fi}, 1$ in $\mathrm{Ge}, 2$ in Le, 2 in Mi, in Pr, 3 in $\mathrm{Pg}, 1$ in Ve. As regards the 23 rising types, we have: 3 in Ba, 5 in $\mathrm{Ca}, 1$ in $\mathrm{Cz}, 1$ in Fi, 1 in Ge, 3 in $\mathrm{Mi}, 2$ in $\mathrm{Pg}, 1$ in Rm, 2 in To, 4 in Ve. Concerning the 17 rise-fall-rising types, we can notice this situation: 4 in $\mathrm{Ba}, 2$ in $\mathrm{Ca}, 1$ in $\mathrm{Cz}, 1$ in $\mathrm{Fi}, 2$ in Ge, 2 in $\mathrm{Le}, 2$ in $\mathrm{Mi}, 1$ in $\mathrm{Pg}$, 1 in To, 1 in Ve.

Regarding the distribution of the 14 mid level-rising ones: 2 in $\mathrm{Ba}, 4$ in $\mathrm{Bg}, 1$ in $\mathrm{Ca}, 1$ in Ge, 1 in Mi, 1 in Pa, 1 in Rm, 2 in To, 1 in Ve; for the 13 fall-low mid level types, there are: 1 in $\mathrm{Ca}, 4$ in $\mathrm{Cz}, 2$ in $\mathrm{Fi}, 1$ in $\mathrm{Pa}, 3$ in $\mathrm{Pg}$, 2 in Ve; for the 13 rise-falling types: 1 in $\mathrm{Ba}, 1$ in $\mathrm{Ca}, 1$ in $\mathrm{Cz}, 1$ in Fi, 1 in Le, 1 in Pa, 1 in Pg, 2 in Rm, 3 in To, 1 in Ve; for the 12 fall-rise-high mid level ones: 2 in Ba, 6 in $\mathrm{Cz}, 2$ in Fi, 1 in Ge, 1 in Pg; for the 5 mid levelfalling ones: 1 in $\mathrm{Cz}, 1$ in Ge, 1 in $\mathrm{Pa}, 1$ in $\mathrm{Pr}, 1$ in Ve; for the 4 mid-levelfall-rising ones: 2 in Mi, 2 in To; for the 3 fall-low mid level-rising ones: 1 in $\mathrm{Pa}, 1$ in $\mathrm{Pr}, 1$ in To; for the 3 mid-level ones: 1 in Fi, 1 in $\mathrm{Pg}, 1$ in Rm; for the 2 rise-high mid level-rising ones: 1 in $\mathrm{Ba}, 1$ in Pr. Then, we find a risehigh mid level type in Pg; a fall-low mid level-falling one in Le; a mid-levelfall-low mid level one in $\mathrm{Ve}$; a mid-level-rise-falling one in $\mathrm{Ge}$; a rise-falllow mid level one in $\mathrm{Ba}$; and a rise-high mid level-falling one in To.

Finally, we may count at least 200 instructions with other very different and more complex kinds of terminal contour and, if we then examine the part of intonative profile that goes from the last turning point, i.e. the last point of $f_{0}$ variation movement, to the end of the utterance, we can find two groups of utterances: the former is constitued by 185 falling movements, the latter by 343 rising movements, both scattered in so several different terminal contours that what emerges is an equally heterogeneous outline.

\section{Conclusion}

So, if we pay attention to those results, we may reach the conclusion that each of the many possible different kinds of terminal contour is capable of meaning, and concretely means, the same deontic value of instruction. Hence we may reasonably conclude that: 1) the terminal contour, like other intonative elements, proves to be not the primary term of modal comparison but only the part of a more complex prosodic game that shows all the limits of current representative models of intonation (Martin 2005, 2009: 69-83) which too often confuse linguistic phenomena dynamics with their representations; 2) each terminal contour type, according to the whole enonciative coordinates system, can mean any modal value and, more generally, make any sense, (Bolinger 1986: 13); 3) the potentially unlimited 
semantic plasticity of intonation is just the evidence of its arbitrary character, which proves its status as an integral part of the linguistic system (Saussure 1916; Bally 1932: par. 39, 44; Fónagy 1987: 82).

\section{References}

Bally, C. 1932. Linguistique générale et linguistique française. Leroux, Paris.

Benveniste, É. 1966. Les niveaux de l'analyse linguistique. In Benveniste, É., Problèmes de linguistique générale, 119-131. Gallimard, Paris.

Bertinetto, P.M., Magno Caldognetto, E. 1993. Ritmo e intonazione, in Sobrero, A. (a cura di) Introduzione all'italiano contemporaneo, 2 voll., Laterza, Roma-Bari, vol. I, 141-92.

Bolinger, D. 1986. Intonation and emotion, Contribution to the Round Table «Phonetics and emotion», in "Quaderni semiotici», 1, 13-21.

Canepari, L. 1985. L’intonazione. Linguistica e paralinguistica, Liguori, Napoli.

Chapallaz, M., 1964. Notes on the Intonation of Questions in Italian. In Abercrombie, D., Fry, D., MacCarthy, P.A.D., Scott, J.L., Trim, J.L.M. (eds), In Honour of Daniel Jones, 306-312.Longmans, London.

Culioli, A., Valeurs aspectuelles et opérations énonciatives: l'aoristique, 1978, in Id., Pour une linguistique de l'énonciation, 3 voll., Ophrys, Paris, 1990-99, vol. II, 127-43.

De Dominicis, A., 1992. Intonazione e contesto. Uno studio su alcuni aspetti del discorso in contesto e delle sue manifestazioni intonative, Edizioni dell'Orso, Alessandria.

Di Russo, D., 2011. Intonazione e modalità nella significazione, Dottorato di Ricerca in Filologia, Linguistica e Letteratura, Università di Roma La Sapienza.

Fónagy, I., 1987. Vocal Expression of Emotions and Attitudes, in «VS. Quaderni di studi semiotici» 47-48, 65-85.

Grize, J.-B., 1990. Logique et langage, Ophrys, Paris.

Karcevskij, S., 1931. Sur la Phonologie de la Phrase, 1931, in «Travaux du Cercle Linguistique de Prague», vol. IV, 188-227.

Le Querler, N., 1996. Typologie des modalités, Presses Univ. de Caen, Caen.

Lepschy, G.C., 1978. Appunti sull'intonazione italiana, in Id., Saggi di linguistica italiana, Il Mulino, Bologna, 127-42.

Lyons, J., 1997. Semantics, 2 vol., Cambridge University Press.

Martin, P., 2009. Intonation du français. Paris, Armand Colin.

Id., Modelli di analisi e sistemi di etichettatura prosodica, AISV, 2005, Salerno.

Palmer, F., 1986. Mood and Modality, Cambridge University Press.

Saussure, F. de, 1916. Cours de linguistique générale. Paris, Payot.

Sorianello, P., 2006. Prosodia. Modelli e ricerca empirica. Roma, Carocci. 